\title{
PENENTUAN KORELASI TINGKAT KEMATANGAN BUAH ALPUKAT (Persea americana mill) TERHADAP GRAVITASI SPESIFIK
}

\section{CORRELATION DETERMINATION OF AVOCADO (Persea americana mill) MATURITY TO SPECIFIC GRAVITY}

\author{
Jusuf Wahyudi 1), Roni Herdian Saputra ${ }^{2)}$ \\ 1) Program Studi Teknik Informatika, Fakultas Ilmu Komputer, Universitas Dehasen \\ Bengkulu \\ ${ }^{2)}$ Program Studi Teknologi Pertanian, Fakultas Pertanian, Universitas Dehasen Bengkulu
}

\begin{abstract}
ABSTRAK
Kebutuhan masyarakat terhadap pangan pada umumnya dan produk hortikultura pada khususnya dari tahun ketahun terus meningkat seiring dengan pertambahan penduduk yang dari tahun ketahun meningkat pula, hal ini akan berdampak pada peningkatan kebutuhan pemenuhan gizi dan polakonsumsi masyarakat. Buah alpukat termasuk buah yang banyak mengandung gizi yang dibutuhkan oleh manusia.

Pada penelitian ini tiga puluh enam buah alpukat yang masing-masing telah diambil data $\mathrm{Gs}_{\mathrm{p}}$ dibiarkan pada suhu kamar kemudian dikontrol setiap hari untuk mengetahui buah yang masak sesuai dengan kode masing-masing. Setelah sekian hari dan seluruh buah alpukat telah masak maka dicari nilai korelasi (r) antara nilai $\mathrm{Gs}_{\mathrm{p}}$ (variabel $\mathrm{Xi}$ ) dengan waktu masak buah (variabel Yi).

Dari penelitian ini diperoleh nilai korelasi antara nilai Gsp buah alpukat (variabel Xi) dengan waktu matang (variabel $\mathrm{Yi}$ ), $\mathrm{r}=0,71$. Dari nilai $\mathrm{r}$ ini diperoleh nilai $\mathrm{t}_{\text {hitung }}=5,336$. Pada taraf nyata $\alpha=0,05$ dan $\mathrm{dk}=30-2=3428$ diperoleh $\mathrm{t}_{\text {tabel }}=2,048$. Ternyata $\mathrm{t}_{\text {hitung }}>\mathrm{t}_{\text {tabel }}, 5,336,1>$ 2,048 sehingga $\mathrm{H}_{\mathrm{a}}$ diterima dan $\mathrm{H}_{\mathrm{o}}$ ditolak atau korelasi antara nilai gravitasi spesifik dengan tingkat kematangan buah alpukat signifikan.
\end{abstract}

Kata Kunci :buah alpukat, gravitasi spesifik, korelasi, tingkat kematangan.

\section{ABSTRACT}

Social community need to food in general and horticulture in particular from year to year continues to increase along with the growth of population too. This will result an increased need for nutrition and consumption patterns including avocado fruit contains many nutrients needed by human.

In this study, 36 (Thirty six) Pleces of avocado which each take the data GS $S_{p}$ is left at room temperature and then contolled every day to find pleces that correspond to each code. After a long day and that all avocado fruit over ripe the find corelation value $(r)$ between $G S_{P}$ value (Variable $\mathrm{Xi}$ ) with ripening time (Variable $\mathrm{Yi}$ ).

From this study obtainable correlation value between $G S_{p}$ value avocado fruit (Variable $X i$ ) with ripening time (Variable Yi ), $r=0,71$. From this value $r$ get $t$ aritmetic $=5,336$.

In the real level $a=0,05$ and $d k=30-2=3428$ get $t_{\text {table }}=2,048$ it turs out $t_{\text {aritmetic }}>t_{\text {table }}$ 5,336,1 > 2,048 so that Ha accepted and Ho benied or correlation between specific gravity value with increase avocado fruit maturity significant.

Key words : Avocado Fruit, Specific Gravity, correlation, Maturity Level. 


\section{PENDAHULUAN}

Kebutuhan masyarakat terhadap pangan pada umumnya dan produk hortikultura pada khususnya dari tahun ke tahun terus meningkat seiring dengan pertambahan penduduk yang dari tahun ke tahun meningkat pula, hal ini akan berdampak pada peningkatan kebutuhan pemenuhan gizi dan pola konsumsi masyarakat. Kebutuhan akan gizi meliputi sumber karbohidrat, lemak, protein, vitamin, dan mineral. Pola konsumsi masyarakat bergantung pada selera atau bagaimana cara produk pertanian diolah menjadi makanan yang lezat misalnya buah alpukat diolah menjadi es krim. Ini suatu peluang bagi pelaku usaha untuk membuat produk olahan dan bagi petani untuk untuk memasarkan hasil panen.

Produk hortikultura sangat terkenal dengan sumber vitamin dan zat antioksidan. Proses pengolahan produk hortikultura diawali dengan panen pra pasca panen, dan transportasi (Suryadi, 1999). Pada saat pemanenan buah komponen tingkat kematangan sangat menentukan mutu produk yang meliputi rasa, aroma dan penampilan fisik (Septaria 2001).

Produk hortikultura khususnya buahbuahan biasanya dipanen/dipetik pada tingkat kematangan yang belum optimal tetapi dengan harapan masih mendekati mutu dan cita rasa buah yang matang optimal. Hal ini dilakukan mengingat beberapa tujuan tertentu misalnya buah dipanen dalam jumlah yang banyak untuk tujuan penjualan ke daerah yang relatif jauh. Hal ini dapat dimaklumi mengingat produk hortikultura kebanyakan bersifat klimaktrik seperti buah alpukat.Buah klimaktrik adalah buah dengan tingkat kematangan dapat dipacu, dengan demikian untuk beberapa tujuan tertentu misalnya untuk dijual buah tidak cocok dipanen pada matang optimal karena lekas busuk atau cepat rusak dan juga tidak cocok dipanen pada tingkat kematangan jauh dari optimal karena mutu dan cita rasa tidak bagus. Mutu buah yang bagus akan berpengaruh pada kualitas dan harga jual (Rismunandar, 1986).

Penentuan tingkat kematangan buah dapat dilakukan dengan berbagai cara yaitu mulai dari menghitung umur buah sejak penyerbukan bunga, melihat tanda-tanda fisik, metode berat jenis (metode volume air yang dipindahkan) (Muchtadi, 2010). Namun beberapa cara tersebut dianggap tidak efisien karena terlalu membutuhkan ketelitian dan banyak menyita waktu oleh sebab itu perlu dicari cara yang lebih efisien dan mudah dilakukan oleh setiap orang karena tidak menggunakan peralatan yang canggih misalnya perangkat komputer (Ranggana 1986).

Penentuan tingkat kematang buah alpukat ini sebelumnya telah dilakukan oleh 
Wahyudi dan Johan (2011), dengan metode getaran suara menggunakan program komputer. Namun cara demikian tidak efisien dan tidak semua orang memahami atau dapat melakukan mengingat peralatan yang digunakan terlalu mahal yaitu perangkat komputer (Srivastava, 2006).

Oleh karena itu penulis berinisiatif mencari metode penentuan tingkat kematangan buah alpukat yang lebih praktis dan menggunakan peralatanyang setiap orang mampu membelinya, yaitu dengan mengunakan metode gravitasi spesifik. Menurut Tripler (1991), penentuan tingkat kematangan buah alpukat dengan metode grvitasi spesifik pada intinya adalah mencari nilai perbandingan massa buah di udara dengan selisih massa buah di udara dan didalam air kemudian dikalikan dengan kerapatan air.

\section{METODOLOGI PENELITIAN}

\section{Bahan dan Alat}

Bahan pada penelitian ini diambil 30 buah alpukat secara acak dari pohon alpukat. Alat yang digunakan dalam penelitian ini adalah timbangan neraca pegas $(0-1000$ gram) untuk menimbang buah alpukat di udara,dinamometer $1,5 \mathrm{~N}$ (neraca pegas 0 - 150 gram) untuk menimbang buah alpukat didalam air karena neraca pegas (0 -1000 gram) pada waktu menimbang buah didalam air untuk berat buah kurang dari 10 gram tidak terbaca lagi, beban 50 gram dari besi sebagai pemberat waktu menimbang buah alpukat di dalam air, statif untuk dudukan dinamometer waktu menimbang buah didalam air, dan wadah untuk menampung air. Dan peralatan lainnya yang dibutuhkan seperti jarum pentul dan benang untuk menghubungkan buah, beban pemberat, dan dinamometer secara satu kesatuan sewaktu menimbang buah didalam air.

\section{Metode}

Tiga puluh buah alpukat dipanen dari pohon melalui 3 tahap yaitu sepuluh buah tahap awal (awal musim), minggu berikutnya (ke-2)sepuluh buah lagi(tengah musim ), minggu berikutnya (ke-3) lagi sepulu buah(mendekati akhir musim). Hal ini dilakukan sebagai strategi untuk menghindari keseragaman data yang diperoleh atau dengan harapan diperoleh data penelitian yang variatif. Kemudian buah ditimbang satu per satu diudara tanpa pemberat dan dengan pemberat beban besi 50 gram menggunakan neraca pegas.Beban pemberat digunakan jika buah alpukat didalam air kondisinya terapung. Nilai Gsp dihitung dengan rumus

$\mathrm{Gs}_{\mathrm{p}}=\frac{W_{a}}{W_{a}-W_{w}} \mathrm{Gsl}$ (untuk buah alpukat yang kondisinya terendam didalam air) 
$\mathrm{Gs}_{\mathrm{p}}=$

$\frac{W_{a} \text { produk }}{\left[\left(W_{a}-W_{w}\right) \text { produk \& pemberat }-\left(\mathrm{W}_{\mathrm{a}}-\mathrm{W}_{\mathrm{w}}\right) \text { pemberat }\right]} \quad \mathrm{GS}_{1}$ (untuk buah alpukat yang kondisinya terapung didalam air) dimana :

Gsp : gravitasi spesifik produk (buah alpukat)

$\mathrm{W}_{\mathrm{a}}$ : berat produk di udara (gram)

$\mathrm{W}_{\mathrm{w}}$ : berat produk didalam air (gram)

Pemberat : beban besi 50 gram (disimbolkan p)

Gsl : gravitasi spesifik air $\left(10^{3} \mathrm{~kg} / \mathrm{m}^{3}\right)$

Kemudian data gravitasi spesifik buah alpukat dicatat berdasarkan kode masingmasing tiga puluh buah alpukat dalam penelitian ini.
Tiga puluh buah alpukat yang masingmasing telah diambil data $\mathrm{Gs}_{\mathrm{p}}$ dibiarkan pada suhu kamar kemudian dikontrol setiap hari serta didata (dicatat) waktu buah masak sesuai dengan kode masingmasing. Setelah seluruh buah alpukat telah masak maka dicari nilai korelasi (r) antara nilai $\mathrm{Gs}_{\mathrm{p}}$ (variabel $\mathrm{Xi}$ ) dengan waktu masak buah (variabel Yi) dengan persamaan :

$r=\frac{\sum x y}{\sqrt{\left(\sum x^{2}\right)\left(\sum y^{2}\right)}}($ Sumber :Usman dan Akbar, 2006)

dengan nilai $r$ dapat diinterpretasikan pada tabel 1. Sedangkan data dari hasil penelitian disajikan dalam bentuk tabel 2 .

Tabel 1. Interpretasi dari nilai $r$

\begin{tabular}{ll}
\hline \multicolumn{1}{c}{$\mathrm{r}$} & \multicolumn{1}{c}{ Interpretasi } \\
\hline 0 & Tidak berkorelasi \\
$0,01-0,20$ & Sangat rendah \\
$0,21-0,40$ & Rendah \\
$0,41-0,60$ & Agak rendah \\
$0,61-0,80$ & Cukup \\
$0,81-0,99$ & Tinggi \\
1 & Sangat tinggi
\end{tabular}

(Sumber : Usman dan Akbar, 2006)

Tabel 2. Tabel Penolong Untuk Menghitung Nilai Regresi( $r$ ) Tunggal

\begin{tabular}{|c|c|c|c|c|c|c|c|}
\hline No & $X_{i}$ & $Y_{i}$ & $\left(X_{i}-X_{i}\right)=x$ & $\left(Y_{i^{-}} Y_{i}\right)=y$ & $x^{2}$ & $\mathrm{y}^{2}$ & Xу \\
\hline \multicolumn{8}{|l|}{1} \\
\hline \multicolumn{8}{|l|}{2} \\
\hline \multirow{2}{*}{\multicolumn{8}{|c|}{$\begin{array}{l}\cdots \\
\mathrm{N}\end{array}$}} \\
\hline & & & & & & & \\
\hline & $\mathrm{Xi}=$ & $\mathrm{Yi}=$ & 0 & 0 & $\sum x^{2}=$ & $\sum y^{2}=$ & $\sum x y=$ \\
\hline
\end{tabular}

(Sumber : Usman dan Akbar. 2006) 
a. Mencari nilai $r$ dengan dengan mengunakan rumus :

$\mathrm{r}=\frac{\sum x y}{\sqrt{\left(\sum x^{2}\right)\left(\sum y^{2}\right)}}($ Sumber :Usman,

H. 2006)

b. Mencari nilai thitung dengan rumus :

$t_{\text {hitung }}=r \sqrt{\frac{n-2}{1-r^{2}}}$ (Sumber : Usman,

H. 2006)

c. Menentukan kriteria pengujian signifikansi korelasi yaitu :

Jika $-\mathrm{t}_{\text {tabel }} \leq$ thitung $\leq \mathrm{t}_{\text {tabel }}$, maka

$\mathrm{H}_{\mathrm{o}}$ diterima atau korelasinya tidak signifikan.

d. Menentukan $t_{\text {tabel }}$ dengan taraf nyata $\dot{\alpha}=$ 0,05 dan $\mathrm{dk}=\mathrm{n}-2$ pada daftar tabel $\mathrm{t}$.

e. Membuat hipotesis $\mathrm{Ha}$ dan $\mathrm{H}_{\mathrm{o}}$ dalam kalimat
$\mathrm{H}_{\mathrm{a}}$ : Terdapat hubungan yang positif dan signifikan antara gravitasi spesifik dengan tingkat kematangan buah alpukat.

$\mathrm{H}_{\mathrm{o}}$ : : Tidak terdapat hubungan positif dan signifikan antara gravitasi spesifik dengan tingkat kematangan buah alpukat.

\section{HASIL DAN PEMBAHASAN}

\section{Bobot Buah Alpukat}

Bobot buah alpukat yang diproleh dari panen dipohon untuk penelitian yang dilakukan sebanyak tiga kali yakni pada minggu ke-1(14 Maret 2014), minggu ke2 (24 Maret 2014), dan minggu ke-3 (30 Maret 2014) setelah dilakukan penimbangan dapat dilihat pada tabel 3,4 dan 5 .

Tabel 3.Perbandingan bobot buah alpukat yang dipanen pada mingguke-1

\begin{tabular}{ccc} 
Waktu panen & Kode buah & Bobot buah (gr) \\
\hline B01 & 195 \\
B02 & 250 \\
B03 & 130 \\
B04 & 190 \\
B05 Maret 2014 & B06 & 200 \\
& B07 & 215 \\
B08 & 175 \\
B09 & 175 \\
B10 & 175 \\
\hline Rata-rata & 155 \\
\hline
\end{tabular}


Tabel 4. Perbandingan bobot buah alpukat yang dipanen pada minggu ke-2

\begin{tabular}{ccc}
\hline Waktu panen & Kode buah & Bobot buah (gr) \\
\hline B11 & 300 \\
B12 & 310 \\
B13 & 250 \\
B14 & 240 \\
24 Maret 2014 & B15 & 250 \\
B16 & 285 \\
B17 & 335 \\
B18 & 235 \\
B19 & 255 \\
B20 & 220 \\
\hline
\end{tabular}

Tabel 5. Perbandingan bobot buah alpukat yang dipanen pada minggu ke-3

\begin{tabular}{ccc}
\hline Waktu panen & Kode buah & Bobot buah (gr) \\
\hline B21 & 295 \\
B22 & 310 \\
B23 & 280 \\
B24 & 225 \\
30 Maret 2014 & B25 & 325 \\
& B26 & 380 \\
B27 & 260 \\
B28 & 310 \\
B29 & 165 \\
B30 & 445 \\
\hline
\end{tabular}


Dari tabel 3, 4 dan 5 terlihat bahwa semakin bertambah umur buah alpukat maka bobot buah semakin bertambah. Buah alpukat yang dipanen pada minggu ke-1 bobotnya rata-rata 186 gram, selang 10 hari kemudian atau pada minggu ke-2 buah dipanen lagi dan didapatkan bobot buah rata-rata 268 gram, dan selang 6 hari kemudian atau pada minggu ke-3 buah dipanen lagi dan didapatkan bobot buah rata-rata 300 gram. Dari minggu ke-1 hingga minggu ke-2 buah alpukat mengalami peningkatan bobot rata-rata 82gram dan dari minggu ke-2 hingga minggu ke-3 buah alpukat hanya mengalami peningkatan bobot rata-rata 32 gram.Ini dapat dijelaskan karena dari minggu ke-1 hingga minggu ke-2 buah alpukat sedang mengalami fasetua sehingga pertumbuhannya secara keseluruhan meliputi kulit, daging buah, biji, dan kandungan zat-zat lainnya. Sedangkan fase berikutnya adalah fase menuju matang, pertumbuhan buah secara keseluruhan sudah cukup optimal, tingal pertambahan kandungan zat kimiawi saja yang dialami daging buahuntuk matang optimal, misalnya pada masa ini pertumbuhan yang paling banyak adalah perubahan daging buah alpukat yang semula keras dan berasa pahit menjadi lunak dan berasa lemak (flavor khas daging buah alpukat matang). Jika pada daging buah kadar lemaknya meningkat maka sudah pasti kadar airnya berkurang karena gravitasi spesifik (berat jenis) air lebih besar daripada gravitasi spesifik lemak/minyak. Pada suhu ruang gravitasi spesifik air $1000 \mathrm{~kg} / \mathrm{m}^{3}$ dan gravitasi lemak/minyak sekitar $800 \mathrm{~kg} / \mathrm{m}^{3}$.

\section{Nilai Gravitasi Spesifik Buah Alpukat}

Perhitungan nilai gravitasi spesifik buah alpukat dilakukan dengan dua cara yaitu untuk buah alpukat yang teredam dalam air (nilai Gsp $>10^{3}$ ) dan untuk buah alpukat yang terapung dalam air (nilai Gsp $<10^{3}$ ). Menurut Yuwana (2009), untuk produk yang lebih berat dari air maka :

$$
\mathrm{Gs}_{\mathrm{p}}=\frac{\mathrm{w}_{\mathrm{a}}}{\mathrm{W}_{\mathrm{a}}-\mathrm{W}_{\mathrm{w}}} \mathrm{Gsl}
$$

Untuk produk yang lebih ringan dari air sehingga memerlukan benda yang lebih berat dari air sebagai pemberat maka :

$\mathrm{Gs}_{\mathrm{p}}=$

$\frac{\mathrm{W}_{\mathrm{a}} \text { produk }}{\left[\left(\mathrm{W}_{\mathrm{a}}-\mathrm{W}_{\mathrm{W}}\right) \text { produk \& pemberat }-\left(\mathrm{W}_{\mathrm{a}}-\mathrm{W}_{\mathrm{W}}\right) \text { pemberat }\right]}$ $\mathrm{Gs}_{1}$

Keterangan :

Gsp : gravitasi spesifik produk (buah alpukat)

$\mathrm{W}_{\mathrm{a}}$ : berat produk di udara (gram)

$\mathrm{W}_{\mathrm{w}}$ : berat produk didalam air (gram)

Pemberat : beban besi 50 gram (disimbolkan $\mathrm{p}$ )

Gsl : gravitasi spesifik air $\left(10^{3} \mathrm{~kg} / \mathrm{m}^{3}\right)$

Pada hasil penelitian ini setelah dilakukan pengukuran nilai Gsp, ternyata pada saat 
mau menimbang buah alpukat didalam air, ada beberapa buah yang terendam dalam air dan juga ada beberapa buah yang hanya sebagian terendam dalam air (terapung). Berdasarkan perhitungan rumus nilai Gsp, buah yang terapung didalam air ini memerlukan pemberat (p), buah tersebut adalah adalah buah dengan kode B25 sampai dengan B30. Rincian beberapa buah alpukat yang dimaksud setelah dihitung nilai gravitasi spesifiknya dapat dilihat pada tabel 6 dan 7.

Tabel 6. Nilai Gravitasi Spesifik Buah Alpukat yang Terendam dalam air

\begin{tabular}{cccccc}
\hline A & $\mathrm{b}$ & $\mathrm{c}$ & $\mathrm{D}$ & $\mathrm{e}$ & $\mathrm{f}=\mathrm{Gsp}$ \\
\hline B & Wp & Wp & $(\mathrm{b}-\mathrm{c})$ & $(\mathrm{b} / \mathrm{d})=\mathrm{Gsp}$ & (pembulatan) \\
\hline B01 & 195 & 6,5 & 188,5 & 1,03448 & 1,03 \\
B02 & 250 & 6,5 & 245,5 & 1,02669 & 1,03 \\
B03 & 130 & 6,5 & 123,5 & 1,05263 & 1,05 \\
B04 & 190 & 6,0 & 184,0 & 1,03261 & 1,03 \\
B05 & 200 & 5,0 & 195,0 & 1,02564 & 1,03 \\
B06 & 215 & 6,5 & 208,5 & 1,03118 & 1,03 \\
B07 & 175 & 6,0 & 169,0 & 1,03550 & 1,04 \\
B08 & 175 & 7,5 & 167,5 & 1,04478 & 1,04 \\
B09 & 175 & 5,5 & 169,5 & 1,03245 & 1,03 \\
B10 & 155 & 7,0 & 148,0 & 1,04730 & 1,05 \\
B11 & 300 & 5,0 & 295,0 & 1,01695 & 1,02 \\
B12 & 310 & 4,0 & 306,0 & 1,01307 & 1,01 \\
B13 & 250 & 5,0 & 245,0 & 1,02041 & 1,02 \\
B14 & 240 & 5,5 & 234,5 & 1,02345 & 1,02 \\
B15 & 250 & 5,5 & 244,5 & 1,02249 & 1,02 \\
B16 & 285 & 6,0 & 279,0 & 1,02151 & 1,02 \\
B17 & 335 & 6,5 & 328,5 & 1,01979 & 1,02 \\
B18 & 235 & 4,5 & 230,5 & 1,01952 & 1,02 \\
B19 & 255 & 6,5 & 248,5 & 1,02616 & 1,02 \\
B20 & 220 & 5,0 & 215,0 & 1,02326 & 1,02 \\
B21 & 290 & 5,0 & 290,0 & 1,01724 & 1,02 \\
B22 & 310 & 2,5 & 307,5 & 1,00813 & 1,01 \\
B23 & 280 & 6,0 & 274,0 & 1,02190 & 1,02 \\
B24 & 225 & 7,5 & 217,5 & 1,03448 & 1,03 \\
\hline
\end{tabular}

Keterangan $: \mathrm{f}=\mathrm{Gsp}\left(\mathrm{x} 10^{3} \mathrm{~kg} / \mathrm{m}^{3}\right)$ 
Tabel 7.Nilai Gravitasi Spesifik Buah Alpukat yang Terapung dalam air

\begin{tabular}{ccccccccccc}
\hline $\mathrm{A}$ & $\mathrm{B}$ & $\mathrm{c}$ & $\mathrm{d}$ & $\mathrm{e}$ & $\mathrm{F}$ & $\mathrm{g}$ & $\mathrm{H}$ & $\mathrm{i}$ & $\mathrm{J}$ & $\mathrm{k}$ \\
\hline $\mathrm{B}$ & $\mathrm{Wp}$ & $\mathrm{p}$ & $\mathrm{p}$ & $\mathrm{b}+\mathrm{c}$ & & & & & & $\mathrm{x} 10^{3}$ \\
\hline 25 & 325 & 50 & 42 & 375 & 41 & 8 & 334 & 326 & 0,99693 & 1,00 \\
26 & 380 & 50 & 42 & 430 & 20 & 8 & 410 & 402 & 0,94527 & 0,95 \\
27 & 260 & 50 & 42 & 310 & 39 & 8 & 271 & 263 & 0,98859 & 0,99 \\
28 & 310 & 50 & 42 & 360 & 37 & 8 & 323 & 315 & 0,98413 & 0,98 \\
29 & 165 & 50 & 42 & 215 & 40 & 8 & 175 & 167 & 0,98802 & 0,99 \\
30 & 445 & 50 & 42 & 495 & 28 & 8 & 467 & 459 & 0,96950 & 0,97 \\
\hline
\end{tabular}

Keterangan :

B : kode buah $(\mathrm{B} 1, \mathrm{~B} 2, \mathrm{~B} 3 \ldots, \mathrm{Bn})$

Wp : bobot produk di udara (gr)

Wp' : bobot produk di dalam air (gr)

$\mathrm{P} \quad$ : berat pemberat di udara $(\mathrm{gr})$

P' : berat pemberat di dalam air (gr)

Gsp : nilai gravitasi spesifik produk (buah alpukat) x $10^{3} \mathrm{~kg} / \mathrm{m}^{3}$

f $\quad:(\mathrm{Wp}+\mathrm{p})^{\prime}$

g $\quad: c-d$

h $: e-f$

i $: \mathrm{g}-\mathrm{h}$

j $\quad: \frac{\mathrm{b}}{\mathrm{i}}=\mathrm{Gsp}$

$\mathrm{k} \quad$ : pembulatan nilai Gsp

Nilai Gsp pada tabel 6 dan 7 terlihat bahwa rata-rata bobot (berat) buah alpukat berbanding terbalik dengan nilai nilai Gsp.Buah yang dipanen pada minggu ke-1 diperoleh bobot buah yang paling kecil yakni B03dengan bobot 130 gram; nilai Gsp 1,05263 dan bobot buah yang paling besar yakni B02 dengan bobot 250 gram; nilai Gsp 1,02669. Pada minggu ke-2 diproleh bobot buah yang paling kecil yakni B20 dengan bobot 220 gram; nilai Gsp 1,02326 dan bobot buah yang paling besar yakni B12 dengan bobot 310 gram; nilai Gsp 1,01307. Pada minggu ke-3 diproleh bobot buah yang paling kecil yakni B29 dengan bobot buah 165 gram; nilai Gsp 0,98802 dan bobot yang paling besar yakni B30 dengan bobot 445 gram; 
nilai Gsp 0,96950. Artinya rata-rata bobot buah alpukat berbanding terbalik dengan nilai gravitasi spesifik.

\section{Hubungan Nilai Gsp Buah Alpukat dengan Tingkat Kematangan}

Buah alpukat yang telah dihitung nilai Gsp dan dibiarkan pada suhu kamar beberapa hari sehingga menjadi matang, buah alpukat yang paling cepat matang secara alami mengindikasikan memiliki tingkat kematangan paling optimal. Pada pengukuran nilai Gsp, terdapat dua kelompok buah alpukat yakni buah alpukat yang terendam dalam air (berarti Gsp $>10^{3} \mathrm{~kg} / \mathrm{m}^{3}$ ) dimana kelompok ini belum ada jaminan buah matang sempurna (optimal) perlu dilihat dulu nilai Gsp (seberapa jauh nilai Gsp $>10^{3} \mathrm{~kg} / \mathrm{m}^{3}$ ) dan buah alpukat yang terapung di dalam air (berarti Gsp $<10^{3} \mathrm{~kg} / \mathrm{m}^{3}$ ), kelompok ini sudah menjamin buah memiliki tingkat kematangan sempurna (optimal). Hubungan antara nilai Gsp buah alpukat dengan waktu (hari) yang dibutuhkan untuk matang disajikan pada tabel 8 .

Dari tabel 8 diperoleh nilai $\operatorname{rata}^{2} \mathrm{X}_{\mathrm{i}}=1,02$ , $\operatorname{rata}^{2} Y_{i}=7,5, \sum x^{2}=0,015, \sum y^{2}=176,7$ , dan $\sum x y=1,16$. Dari nilai-nilai ini dapat di cari korelasi ( $\mathrm{r}$ hitung) antara nilai Gsp $\left(\mathrm{X}_{\mathrm{i}}\right)$ dengan waktu matang $\left(\mathrm{Y}_{\mathrm{i}}\right)$ :

$$
\mathrm{r}=\frac{\sum x y}{\sqrt{\left(\sum x^{2}\right)\left(\sum y^{2}\right)}}=\frac{1,16}{\sqrt{(0,015)(176,7)}}=
$$
$\frac{1,16}{\sqrt{2,651}}=\frac{1,16}{1,63}=0,71$ dari nilai $\mathrm{r}$ ini dicari nilai thitungdengan rumus :

$$
\begin{aligned}
& \mathrm{t}_{\text {hitung }}=\mathrm{r} \sqrt{\frac{n-2}{1-r^{2}}}=0,71 \sqrt{\frac{30-2}{1-0,71^{2}}}= \\
& 0,71 \sqrt{\frac{28}{1-0,5041}}=0,71 \sqrt{\frac{28}{0,4959}}= \\
& 0,71 \sqrt{56,46}=5,336 \text { sehingga } \\
& \text { diperoleh } t_{\text {hitung }}=5,336 .
\end{aligned}
$$

Pada taraf nyata $\alpha=0,05$ dan $\mathrm{dk}=30-2=$ 28 diperoleh $t_{\text {tabel }}=2,048$. Ternyata $t_{\text {hitung }}>$ $t_{\text {tabel }}, 5,336>2,048$ sehingga $\mathrm{H}_{\mathrm{a}}$ diterima dan $\mathrm{H}_{\mathrm{o}}$ ditolak atau korelasi antara nilai gravitasi spesifik dengan tingkat kematangan buah alpukat signifikan.Nilai Gsp berbanding terbalik dengan tingkat kematangan, semakin kecil nilai Gsp maka tingkat kematangan buah alpukat semakin tinggi (jumlah hari yang dibutuhkan buah untuk masak semakin kecil). Pada table 4.6 rata-rata nilai Gsp buah alpukat $1,02 \times 10^{3} \mathrm{~kg} / \mathrm{m}^{3}$ dan ratarata waktu masak buah alpukat $7-8$ hari setelah dipanen dan dibiarkan pada suhu kamar. 
Tabel 8. Korelasi nilai Gsp dengan waktu matang (hari)

\begin{tabular}{|c|c|c|c|c|c|c|c|}
\hline \multirow{2}{*}{ B } & \multirow{2}{*}{$\begin{array}{l}\text { Gsp } \\
(\mathrm{Xi})\end{array}$} & \multirow{2}{*}{$\frac{\text { Waktu masak }}{\text { (Yi) }}$} & \multirow{2}{*}{$\frac{\text { Xi-rata }^{2}}{(\mathrm{x})}$} & \multicolumn{4}{|l|}{ Yi-rata $^{2}$} \\
\hline & & & & (y) & $\mathrm{x}^{2}$ & $\mathrm{y}^{2}$ & xy \\
\hline 01 & 1,03 & 10 & 0.0127 & 2.3333 & 0.00016 & 5.4444 & 0.0296 \\
\hline 02 & 1,03 & 10 & 0.0127 & 2.3333 & 0.00016 & 5.4444 & 0.0296 \\
\hline 03 & 1,05 & 10 & 0.0327 & 2.3333 & 0.00107 & 5.4444 & 0.0762 \\
\hline 04 & 1,03 & 9 & 0.0127 & 1.3333 & 0.00016 & 1.7778 & 0.0169 \\
\hline 05 & 1,03 & 7 & 0.0127 & -0.6667 & 0.00016 & 0.4444 & -0.0084 \\
\hline 06 & 1,03 & 10 & 0.0127 & 2.3333 & 0.00016 & 5.4444 & 0.0296 \\
\hline 07 & 1,04 & 9 & 0.0227 & 1.3333 & 0.00051 & 1.7778 & 0.0302 \\
\hline 08 & 1,04 & 14 & 0.0227 & 6.3333 & 0.00051 & 40.1111 & 0.1436 \\
\hline 09 & 1,03 & 8 & 0.0127 & 0.3333 & 0.00016 & 0.1111 & 0.0042 \\
\hline 10 & 1,05 & 13 & 0.0327 & 5.3333 & 0.00107 & 28.4444 & 0.1742 \\
\hline 11 & 1,02 & 7 & 0.0027 & -0.6667 & 7.11E-06 & 0.4444 & -0.0018 \\
\hline 12 & 1,01 & 8 & -0.007 & 0.3333 & $5.38 \mathrm{E}-05$ & 0.1111 & -0.0024 \\
\hline 13 & 1,02 & 7 & 0.0027 & -0.6667 & 7.11E-06 & 0.4444 & -0.0018 \\
\hline 14 & 1,02 & 8 & 0.0027 & 0.3333 & 7.11E-06 & 0.1111 & 0.0009 \\
\hline 15 & 1,02 & 9 & 0.0027 & 1.3333 & 7.11E-06 & 1.7778 & 0.0036 \\
\hline 16 & 1,02 & 6 & 0.0027 & -1.6667 & 7.11E-06 & 2.7778 & -0.0044 \\
\hline 17 & 1,02 & 8 & 0.0027 & 0.3333 & 7.11E-06 & 0.1111 & 0.0009 \\
\hline 18 & 1,02 & 7 & 0.0027 & -0.6667 & 7.11E-06 & 0.4444 & -0.0018 \\
\hline 19 & 1,03 & 8 & 0.0127 & 0.3333 & 0.00016 & 0.1111 & 0.0042 \\
\hline 20 & 1,02 & 8 & 0.0027 & 0.3333 & 7.11E-06 & 0.1111 & 0.0009 \\
\hline 21 & 1,02 & 6 & 0.0027 & -1.6667 & 7.11E-06 & 2.7778 & -0.0044 \\
\hline 22 & 1,01 & 7 & -0.007 & -0.6667 & $5.38 \mathrm{E}-05$ & 0.4444 & 0.0049 \\
\hline 23 & 1,02 & 3 & 0.0027 & -4.6667 & 7.11E-06 & 21.7778 & -0.0124 \\
\hline 24 & 1,03 & 8 & 0.0127 & 0.3333 & 0.00016 & 0.1111 & 0.0042 \\
\hline 25 & 1,00 & 7 & -0.017 & -0.6667 & 0.00030 & 0.4444 & 0.0116 \\
\hline 26 & 0,95 & 5 & -0.067 & -2.6667 & 0.00453 & 7.1111 & 0.1796 \\
\hline 27 & 0,99 & 4 & -0.027 & -3.6667 & 0.00075 & 13.4444 & 0.1002 \\
\hline 28 & 0,98 & 6 & -0.037 & -1.6667 & 0.00139 & 2.7778 & 0.0622 \\
\hline 29 & 0,99 & 4 & -0.027 & -3.6667 & 0.00075 & 13.4444 & 0.1002 \\
\hline 30 & 0,97 & 4 & -0.047 & -3.6667 & 0.00224 & 13.4444 & 0.1736 \\
\hline & rata $^{2}$ & rata $^{2}$ & & & $\sum x^{2}=$ & $\sum y^{2}$ & $\sum x y$ \\
\hline & 1,02 & 7,5 & 0 & 0 & 0,015 & 176,7 & 1,16 \\
\hline
\end{tabular}

Keterangan : B01 s/d B10 dipanen pada minggu k-1, B11 s/d B20 dipanen pada minggu ke-2, dan B21 s/d B30 dipanen pada minggu ke-3. 


\section{SIMPULAN}

Nilai gravitasi spesifik buah alpukat dalam penelitian ini berbanding terbalik dengan rata-rata berat (bobot) buahdan nilai korelasi (r) antara gravitasi spesifik dengan waktu masak dalam penelitian ini sebesar 0,71 thitung sebesar 5,336, dan $t_{\text {tabel }} 2,048$. Karena $t_{\text {hitung }}>t_{\text {tabel }}$ sehingga Ha diterima dan Ho ditolak atau korelasi antara nilai gravitasi spesifik dengan tingkat kematangan buah alpukat signifikan.

\section{DAFTAR PUSTAKA}

Muchtadi. 2010. Ilmu Pengetahuan Bahan Pangan. CV. Alfabeta. Bogor

Ranggana. 1986. Analisis And Quality Control For Fruit And Vegetable Products. $2^{\text {nd }} \mathrm{ED}$, Tata Mc Grow-
Hill Publishing Co. Ltd, New Delhi.

Rismunandar. 1986. Memperbaiki Lingkungan Dengan Bercocok Tanam Jambu Mede \& Advokat. Sinar Baru. Bandung.

Rismunandar, 1986.Mengenal Tanaman Buah-buahan. Sinar Baru. Bandung.

Srivastava AC, 2006. Teknik Instrumentasi. Universitas Indonesia. Jakarta.

Septaria, N. 2001. Membuat Tanaman Cepat Berbuah. Penebar Swadaya. Jakarta

Suryadi. 1999. Budidaya Tanaman BuahBuahan. Karya Anda. Surabaya.

Tipler. 1991. Fisika Untuk Sains dan Teknik. Erlangga. Jakarta.

Usman, H. \& Akbar. 2006. Pengantar Statistik. Bumi Aksara. Yogyakarta.

Yuwana. 2009. Sifat Fisik Produk Pertanian. BPFP UNIB. Bengkulu. 